\title{
Clinical and Laboratory Features in Anti-NF155 Autoimmune Nodopathy
}

\begin{abstract}
Lorena Martín-Aguilar, MD, PhD, * Cinta Lleixà, MSc, * Elba Pascual-Goñi, MD, PhD, Marta Caballero-Ávila, MD, Laura Martínez-Martínez, MD, PhD, Jordi Díaz-Manera, MD, PhD, Ricard Rojas-García, MD, PhD, Elena Cortés-Vicente, MD, PhD, Janina Turon-Sans, MD, Noemi de Luna, PhD, Xavier Suárez-Calvet, PhD, Eduard Gallardo, PhD, Yusuf Rajabally, MD, Sangeeta Scotton, MD, Bart C. Jacobs, MD, PhD, Adája Baars, MD, Andrea Cortese, MD, PhD, Elisa Vegezzi, MD, Romana Höftberger, MD, Fritz Zimprich, MD,

Cornelia Roesler, MD, Eduardo Nobile-Orazio, MD, PhD, Giuseppe Liberatore, MD, Fu Liong Hiew, MD, Alicia Martínez-Piñeiro, MD, Alejandra Carvajal, MD, Raquel Piñar-Morales, MD, Mercedes Usón-Martín, MD, Olalla Albertí, MD, Maria Ángeles López-Pérez, MD, Fabian Márquez, MD, Julio Pardo-Fernández, MD, PhD, Laura Muñoz-Delgado, MD, Macarena Cabrera-Serrano, MD, PhD, Nicolau Ortiz, MD, PhD,

Manuel Bartolomé, MD, Özgür Duman, MD, Vera Bril, MD, Darwin Segura-Chávez, MD, Kalliopi Pitarokoili, MD, Claudia Steen, MD, Isabel IIla, MD, PhD, and Luis Querol, MD, PhD
\end{abstract}

Neurol Neuroimmunol Neuroinflamm 2022;9:e1098. doi:10.1212/NXI.0000000000001098

\section{Abstract}

\section{Background and Objectives}

To study the clinical and laboratory features of antineurofascin-155 (NF155)-positive autoimmune nodopathy (AN).

\section{Methods}

Patients with anti-NF155 antibodies detected on routine immunologic testing were included. Clinical characteristics, treatment response, and functional scales (modified Rankin Scale [mRS] and Inflammatory Rasch-built Overall Disability Scale [I-RODS]) were retrospectively collected at baseline and at the follow-up. Autoantibody and neurofilament light (NfL) chain levels were analyzed at baseline and at the follow-up.

\section{Results}

Forty NF155+ patients with AN were included. Mean age at onset was 42.4 years. Patients presented with a progressive (75\%), sensory motor (87.5\%), and symmetric distalpredominant weakness in upper $(97.2 \%)$ and lower extremities $(94.5 \%)$, with tremor and ataxia $(75 \%)$. Patients received a median of $3(2-4)$ different treatments in 46 months of median follow-up. Response to IV immunoglobulin $(86.8 \%)$ or steroids $(72.2 \%)$ was poor in most patients, whereas $77.3 \%$ responded to rituximab. HLA-DRB1*15 was detected in 91.3\% of patients. IgG4 anti-NF155 antibodies were predominant in all patients; antiNF155 titers correlated with mRS within the same patient $(r=0.41, p=0.004)$. Serum NfL (sNfL) levels were higher in anti-NF155+ AN than in healthy controls (36.47 vs $7.56 \mathrm{pg}$ / $\mathrm{mL}, p<0.001)$ and correlated with anti-NF155 titers $(r=0.43, p=0.001)$, with I-RODS at baseline $(r=-0.88, p<0.001)$ and with maximum I-RODS achieved $(r=-0.58, p=0.01)$. Anti-NF155 titers and sNfL levels decreased in all rituximab-treated patients.

\author{
Correspondence \\ Dr. Querol \\ Iquerol@santpau.cat
}

MORE ONLINE

(II) Class of Evidence

Criteria for rating therapeutic and diagnostic studies

NPub.org/coe

\begin{abstract}
*These authors contributed equally to this work as co-first authors.
From the Neuromuscular Diseases Unit (L.M.-A., C.L., E.P.-G., M.C.-Á., R.R.-G., E.C.-V., J.T.-S., E.N.-O., I.I., L.Q.), Department of Neurology, Hospital de La Santa Creu I Sant Pau, Universitat Autònoma de Barcelona; Biomedical Research Institute Sant Pau (IIB Sant Pau) (L.M.-A., C.L., E.P.-G., M.C.-Á., J.D.-M., E.C.-V., X.S.-C., E.G.); Immunology Department (L.M.-M.), Hospital de La Santa Creu I Sant Pau, Universitat Autònoma de Barcelona, Spain; Centro para La Investigación Biomédica en Red en Enfermedades Raras (CIBERER) (J.D.-M., R.R.-G., E.C.-V., N.L., X.S.-C., E.G., I.I, L.Q.); University Hospital Birmingham (Y.R., S.S.), UK; Erasmus Medical Center (B.C.J., A.B.), Rotterdam, the Netherlands; IRCCS Mondino Foundation (Andrea Cortese, E.V.), Pavia, Italy; Department of Neurology (R.H., F.Z.), Medical University of Vienna; Paracelsus Medical University (C.R.), Salzburg, Austria; IRCCS Humanitas Research Hospital (G.L.), Milan University, Rozzano, Italy; Kuala Lumpur General Hospital (F.L.H.), Jalan Pahang, Kuala Lumpur, Malaysia; Hospital Universitari Germans Trias I Pujol (A.M.-P.), Badalona; Hospital Universitario Virgen de Las Nieves (Alejandra Carvajal), Granada, Spain; Hospital Universitario Clínico San Cecilio (R.P.-M.), Granada; Hospital Son Llàtzer (M.U.-M.), Palma de Mallorca; Hospital San Jorge (O.A.), Huesca, España; Hospital San Pedro (M.Á.L.-P.), Logroño; Hospital Universitari Josep Trueta (F.M.), Girona; Hospital Clínico Universitario de Santiago (J.P.-F.), Santiago de Compostela; Hospital Universitario Virgen Del Rocío (L.M.-D., M.C.-S.), Sevilla; Hospital Universitari Sant Joan (N.O.), Reus; Complejo Asistencial de Ávila (M.B.), Ávila, Spain; Akdeniz University (Ö.D.), Antalya, Turkey; Toronto General Hospital (V.B.), University Health Network, University of Toronto, Canada; Instituto Nacional de Ciencias Neurológicas. Lima (D.S.-C.), Perú; St. Josef-Hospital (K.P.), Ruhr-University Bochum; and Sant Joseph Hospital (C.S.), Berlin, Germany.
\end{abstract}

Go to Neurology.org/NN for full disclosures. Funding information is provided at the end of the article.

The Article Processing Charge was funded by authors.

This is an open access article distributed under the terms of the Creative Commons Attribution-NonCommercial-NoDerivatives License 4.0 (CC BY-NC-ND), which permits downloading

and sharing the work provided it is properly cited. The work cannot be changed in any way or used commercially without permission from the journal. 


\section{Glossary}

CBA = cell-based assay; $\mathbf{C I D P}=$ chronic inflammatory demyelinating polyradiculoneuropathy; $\mathbf{C M A P}=$ compound muscle action potential; CNTN1 = contactin-1; EMG = electromyography; GBS = Guillain-Barré syndrome; HC = Healthy control; HLA = human leukocyte antigen; ICC = immunocytochemistry; I-RODS = Inflammatory Rasch-built Overall Disability Scale; IVIg = IV immunoglobulin; mRS = modified Rankin Scale; NCS = nerve conduction study; NF140 = neurofascin-140; NF155 = neurofascin155; NF186 = neurofascin-186; OD = optical density; PLEX = plasma exchange; sNfL = serum neurofilament light chain.

\section{Discussion}

Anti-NF155 AN presents a distinct clinical profile and good response to rituximab. Autoantibody titers and sNfL are useful to monitor disease status in these patients. The use of untagged-NF155 plasmids minimizes the detection of false anti-NF155+ cases.

\section{Classification of Evidence}

This study provides Class IV evidence that anti-NF155 antibodies associate with a specific phenotype and response to rituximab.

Chronic inflammatory demyelinating polyradiculoneuropathy (CIDP) is a clinically and pathologically diverse autoimmune syndrome of the peripheral nervous system, causing significant disability. ${ }^{1,2}$ Disease-specific antibodies targeting proteins at the node and paranode of Ranvier, such as neurofascin 155 (NF155), ${ }^{3}$ nodal neurofascins (NF186 and NF140), ${ }^{4}$ contactin1 (CNTN1), ${ }^{5}$ or CNTN-1/caspr-1, ${ }^{6,7}$ have been described in small subsets of patients with CIDP sharing immunopathologic mechanisms, clinical features, and treatment response and differing from those of typical CIDP. ${ }^{8,9}$ This has led to the appearance of the autoimmune nodopathy (AN) diagnostic category in the recent update of the European Academy of Neurology/ Peripheral Nerve Society CIDP diagnostic guidelines. ${ }^{10}$

Previous case series describe the association of anti-NF155 antibodies with predominantly distal motor involvement, ataxia and low-frequency tremor with cerebellar features, ${ }^{3,11}$ marked nerve conduction abnormalities, ${ }^{12}$ and $\mathrm{DRB}^{*} 15$ human leukocyte antigen (HLA) Class II alleles. ${ }^{13}$ Moreover, these patients respond poorly to IV immunoglobulin (IVIg) and usually well to rituximab. ${ }^{14}$ Anti-NF155 antibodies, almost always of the IgG4 isotype, ${ }^{15}$ are pathogenic according to passive transfer experiments in animal models ${ }^{16}$ and pathologic studies detecting IgG4 deposition and axoglial junction dissection at the paranode (in the absence of classical macrophage-mediated demyelination). ${ }^{17}$ Recently, high serum neurofilament light chain (sNfL) levels were described in a subset of patients with anti-NF155+ AN. ${ }^{18}$

Our work describes the clinical, immunologic, biomarker, treatment response and prognostic features of the largest antiNF155+ AN cohort so far.

\section{Methods}

\section{Protocol Approvals, Registrations, and Patient Consents}

In this multicenter retrospective observational study, we included all sera reacting against NF155 transfected cells and identified during routine testing for nodal/paranodal antibodies. The samples were obtained between May 2010 and December 2020. These patients were selected for further characterization between May 2020 and December 2020. Demographic and clinical data at onset and during follow-up were collected in a coded database. This study was conducted according to a protocol approved by the Ethics Committee of the Hospital de la Santa Creu i Sant Pau. All patients gave written informed consent to participate in the study.

\section{Data and Sample Collection}

Data were collected retrospectively by patients' neurologists in 24 different centers by chart review. European Academy of Neurology/Peripheral Nerve Society diagnostic criteria for $\mathrm{CIDP}^{19}$ were assessed, and patients were classified as having definite, probable, or possible CIDP. Demographic data (age and gender) and clinical features (initial diagnosis, time to nadir, the presence of weakness or sensory deficits, presence of ataxia, and tremor) were collected. Clinical presentation was defined as sensorimotor, pure motor, or pure sensory/ ataxic. The results of routine nerve conduction studies (NCS), CSF examination, and treatments were also collected. As an electrophysiologic marker of axonal damage, we used the lowest (left or right) median nerve compound muscle action potential (CMAP) negative peak amplitude and, when available, the presence of spontaneous activity in the electromyography (EMG) at the tibialis anterior muscle. CSF protein levels higher than $0.45 \mathrm{~g} / \mathrm{L}$ were considered relevant. ${ }^{20}$ Disability scores were collected at nadir and at the follow-up, including the modified Rankin Scale $(\mathrm{mRS})^{21}$ and the Inflammatory Rasch-built Overall Disability Scale (IRODS) scores ${ }^{22}$ (from 0 to 100; 100 indicating no disability), when available. Response to therapy was defined as a good response, partial response, or no response as classified by their primary neurologists after chart review of the neurologic examination. For rituximab-treated patients, mRS was prospectively collected pretreatment and, at least, once posttreatment; infusion protocol and adverse events (infusion reactions and infections) were also collected. Serum 
samples were obtained at diverse time points during routine autoantibody testing and stored at $-80^{\circ} \mathrm{C}$ until needed.

\section{Anti-NF155 Antibody Detection and Titration}

Serum antibodies against NF155 were analyzed in the same laboratory using a cell-based assay (CBA) with human recombinant NF155-transfected HEK293 cells as previously described. ${ }^{3,23}$ The DDK-myc-tagged RC228652 NF155 plasmid (OriGene, Rockville, MD) was used for initial anti-NF155 detection, and the untagged EX-Z7183M02 NF155 plasmid (GeneCopoeia, Rockville, MD) was used for false positive detection in those patients with discrepant results in the CBA and the ELISA. ELISA was used as a confirmatory test and for isotype identification and titration, as previously described. ${ }^{3}$ Optical density (OD) was measured at $450 \mathrm{~nm}$ with a Multiskan ELISA reader. Blank OD was subtracted to NF155 OD to control for unspecific background signal. The samples were considered positive by ELISA when they had a $\Delta$ OD higher than average healthy control (HC) $\Delta$ OD plus 2 SD. Titer variation within the same patient was expressed as the percentage of titer change compared with pretreatment levels. All samples were tested under the same conditions.

\section{Serum NfL Measurements}

sNfL levels were measured in all available anti-NF155 AN patient samples and compared with $78 \mathrm{HCs}$, using the Simoa NF-light kit in the SR-X Immunoassay Simoa analyzer (Quanterix Corp, Boston, MA), as previously described. ${ }^{24}$ The samples were analyzed in duplicates following the manufacturer's instructions and standard procedures. All NfL values were within the linear ranges of the assay. The intraassay and interassay coefficients of variation at intermediate level $(15.25 \mathrm{pg} / \mathrm{mL})$ were $3.9 \%$ and $9.5 \%$, respectively.

\section{HLA Genotyping}

Genomic DNA from the peripheral blood from patients with anti-NF155+ with AN was extracted following standard protocols. HLA-DRB1 and HLA-DQB1 genotypes were analyzed as previously described. ${ }^{13}$

\section{Statistical Analysis}

A descriptive data analysis was performed. Descriptive statistics are shown as mean $( \pm S D)$ or median (interquartile range) in continuous variables and as frequencies (percentages) in categorical variables. Comparisons between patients with anti-NF155+ AN and HC were performed by the Wilcoxon rank-sum test. The Kruskal-Wallis test was used to compare groups. Wilcoxon-Matched Pairs Signed Rank test was used to compare baseline anti-NF155 titters and sNfL levels at different time points. We used the Spearman coefficient to assess correlation between variables.

Statistical significance for all analyses was set at 0.05 (2-sided). All statistical analyses were performed with GraphPad Prism v8 and SPSS Statistics version 23 (IBM Corp).

\section{Data Availability}

Anonymized data not published within this article will be made available by request from any qualified investigator.

\section{Results}

\section{Anti-NF155 Autoantibody Screening}

We detected 44 sera with a positive staining in the screening NF155 CBA and negative staining in the NF140/NF186 CBA. After performing a confirmatory study with anti-NF155 ELISA, 40 patients were confirmed true positives with ELISA and were selected for further characterization. The other 4 patients were classified as false positives in the CBA (9.1\%). We used an untagged neurofascin- 155 plasmid and confirmed that those 4 patients were negative when the myc-DDK tag was removed (eFigure 1, links.lww.com/NXI/A641).

\section{Clinical Features of Anti-NF155 Patients With AN}

Thirty-nine patients with anti-NF155+ fulfilled the CIDP diagnostic criteria; in 1 patient, antibodies were detected postmortem (supplementary results, links.lww.com/NXI/A641). Nine patients were previously reported in other series. $3,14,15,25,26$ The initial diagnosis was CIDP for most patients (80\%), but 5 patients were initially diagnosed with Guillain-Barré syndrome (GBS). Patients with anti-NF155+ AN had a median age at onset of 42.4 years and were predominantly men $(72.5 \%)$. The most frequent clinical presentation was sensory motor $(87.5 \%)$, and most patients had a progressive (75\%) and chronic $(67.5 \%)$ clinical course. Most patients had a symmetric weakness with distal predominance in upper (97.2\%) and lower extremities (94.5\%). The sensory deficit was symmetric and more frequent in lower (97.5\%) than in upper extremities (67.5\%). Seventy-five percent of patients had tremor and ataxia (of which, 5 had only ataxia, 5 tremor, and 25 a combination of both). Tremor was classified as intention tremor or action tremor in 18 patients (60\%). Thirty percent of patients had cranial nerve involvement: bilateral facial palsy was the most frequent (70\%), and 2 patients had bilateral optic neuritis confirmed by evoked potentials ${ }^{27}$ with normal brain and spine MRI and negative MOG and antiaquaporin- 4 antibodies. Further information about disease characteristics is detailed in Table 1.

Regarding nerve conduction studies, 38 patients fulfilled definite electrodiagnostic European Academy of Neurology/ Peripheral Nerve Society criteria for CIDP, ${ }^{19} 1$ patient was defined as possible CIDP, and 1 patient did not have nerve conduction studies performed because diagnosis was confirmed postmortem. We collected 33 (82.5\%) NCS in which only $26(65 \%)$ had needle EMG available. Median amplitude of distal CMAPs of different nerves are shown in eTable 1 (links.lww.com/NXI/A641). Seventeen of 26 patients (65.4\%) had spontaneous activity on EMG. CSF was examined in 37 (92.5\%) patients; most patients had less than 5 cells in CSF (72.2\%), and all patients had high CSF protein levels with a median of $2 \mathrm{~g} / \mathrm{L}(0.95-3.67)$. 
Table 1 Demographic and Clinical Characteristics of Patients With NF155+ AN

\begin{tabular}{|c|c|}
\hline \multicolumn{2}{|l|}{ Baseline characteristics } \\
\hline Age at onset (mean \pm SD) & $42.40 \pm 19.48$ \\
\hline Age at diagnosis (mean $\pm S D)$ & $43.25 \pm 19.30$ \\
\hline Sex (male; n, \%) & $29(72.5 \%)$ \\
\hline \multicolumn{2}{|l|}{ Initial diagnosis (n, \%) } \\
\hline CIDP & $32(80 \%)$ \\
\hline GBS & $5(12.5 \%)$ \\
\hline Sensory neuropathy & $1(2.5 \%)$ \\
\hline Demyelinating neuropathy & $1(2.5 \%)$ \\
\hline Cervical myelopathy & $1(2.5 \%)$ \\
\hline \multicolumn{2}{|l|}{ CIDP clinical course (n, \%) } \\
\hline Progressive & $30(75 \%)$ \\
\hline Relapsing-remitting & $10(25 \%)$ \\
\hline \multicolumn{2}{|l|}{ Time to nadir (n, \%) } \\
\hline Acute (<1 mo) & $2(5 \%)$ \\
\hline Subacute (1-2 mo) & $11(27.5 \%)$ \\
\hline Chronic (>2 mo) & $27(67.5 \%)$ \\
\hline \multicolumn{2}{|l|}{ Clinical presentation (n, \%) } \\
\hline Sensory motor & $35(87.5 \%)$ \\
\hline Pure sensory/ataxic & $4(10 \%)$ \\
\hline Pure motor & $1(2.5 \%)$ \\
\hline \multicolumn{2}{|l|}{ Weakness (n, \%) } \\
\hline Upper extremity weakness & $35(87.5 \%)$ \\
\hline Symmetric & $33(94.3 \%)$ \\
\hline Proximal and distal & $15(42.9 \%)$ \\
\hline Distal & $19(54.3 \%)$ \\
\hline Proximal & $1(2.9 \%)$ \\
\hline Lower extremity weakness & 37 (92.5\%) \\
\hline Symmetric & $34(91.9 \%)$ \\
\hline Proximal and distal & $17(45.9 \%)$ \\
\hline Distal & $18(48.6 \%)$ \\
\hline Proximal & $2(5.4 \%)$ \\
\hline \multicolumn{2}{|l|}{ Sensory deficit $(n, \%)$} \\
\hline Arm sensory deficit & $27(67.5 \%)$ \\
\hline Symmetric & $26(96.3 \%)$ \\
\hline \multicolumn{2}{|l|}{ Modality } \\
\hline Vibration & $16(59.3 \%)$ \\
\hline Pinprick & $16(59.3 \%)$ \\
\hline
\end{tabular}

Table 1 Demographic and Clinical Characteristics of Patients With NF155+ AN (continued)

\begin{tabular}{|c|c|}
\hline \multicolumn{2}{|l|}{ Baseline characteristics } \\
\hline Superficial sensation & $22(81.5 \%)$ \\
\hline Leg sensory deficit & $39(97.5 \%)$ \\
\hline Symmetric & $38(95 \%)$ \\
\hline \multicolumn{2}{|l|}{ Modality } \\
\hline Vibration & $37(92.5 \%)$ \\
\hline Pinprick & $32(80 \%)$ \\
\hline Superficial sensation & $31(77.5 \%)$ \\
\hline \multicolumn{2}{|l|}{ Reflexes (n, \%) } \\
\hline Absent & $30(75 \%)$ \\
\hline Decreased & $10(25 \%)$ \\
\hline Ataxia (n, \%) & $30(75 \%)$ \\
\hline Tremor (n, \%) & $30(75 \%)$ \\
\hline Cranial nerve involvement ( $n, \%)$ & $12(30 \%)$ \\
\hline Bilateral facial palsy & 7 \\
\hline Ophthalmoparesis & 3 \\
\hline Optic nerve & 2 \\
\hline \multicolumn{2}{|l|}{ Clinical scales } \\
\hline \multicolumn{2}{|l|}{ mRS (median, IQR) } \\
\hline Sampling $(n=27)$ & $3(2-4)$ \\
\hline Maximum $(n=37)$ & $4(2-4)$ \\
\hline Final $(n=37)$ & $2(1-3)$ \\
\hline \multicolumn{2}{|l|}{ I-RODS (median, IQR) } \\
\hline Sampling $(n=14)$ & $49(38-68)$ \\
\hline Maximum $(n=17)$ & $40(29-57)$ \\
\hline Final $(n=22)$ & $59(54-88)$ \\
\hline
\end{tabular}

Abbreviations: $\mathrm{AN}=$ autoimmune nodopathy; $\mathrm{CIDP}=$ chronic inflammatory demyelinating polyradiculoneuropathy; GBS = Guillain-Barré syndrome; IRODS = Inflammatory Rasch-built Overall Disability Scale; IQR = interquartile range; $\mathrm{mRS}=$ modified Rankin Scale.

\section{Treatment Response and Clinical Follow-up}

The median number of treatments received was 3 (2-4). Most patients were treated with IVIg (95\%) and/or corticosteroids (90\%), and approximately half of patients (46.2\%) were treated with plasma exchange (PLEX) with a median number of sessions of 6 (5-9). Twenty-three patients $(57.5 \%)$ were treated with rituximab, and 1 patient was included in a blinded clinical trial of rituximab vs placebo. Of those patients treated with rituximab $(\mathrm{n}=23), 13$ were also treated with plasma exchange before starting rituximab, and 10 patients were treated with rituximab alone. Nine patients were treated with azathioprine, and 8 patients received other 
Table 2 Treatment and Clinical Response

\begin{tabular}{|c|c|c|c|}
\hline Treatment & $\begin{array}{l}\text { No. of } \\
\text { patients } \\
(n, \%)\end{array}$ & $\begin{array}{l}\text { Response } \\
(n, \%)\end{array}$ & Dose/Protocol \\
\hline IVIg & $38(95 \%)$ & $\begin{array}{l}\text { Yes: } 5 \text { (13.1\%) } \\
\text { Partial: } 9 \\
\text { (23.7\%) } \\
\text { No: } 24(63.2 \%)\end{array}$ & $2 \mathrm{~g} / \mathrm{kg}$ per course \\
\hline Steroids & $36(90 \%)$ & $\begin{array}{l}\text { Yes: } 10(27.8 \%) \\
\text { Partial: } 16 \\
(44.4 \%) \\
\text { No: } 10(27.8 \%)\end{array}$ & $\begin{array}{l}1 \mathrm{mg} / \mathrm{kg} / \mathrm{d}: 23(63.9 \%) \\
\text { MP iv pulse: } 4(11.1 \%) \\
\text { MP iv pulse + mg/kg/d: } 5 \\
(13.9 \%) \\
\text { Others: } 4(11.1 \%)\end{array}$ \\
\hline PLEX & $18(46.2 \%)$ & $\begin{array}{l}\text { Yes: } 7(38.9 \%) \\
\text { Partial: } 6 \\
(33.3 \%) \\
\text { No: } 5(27.8 \%)\end{array}$ & $\begin{array}{l}\text { No of sessions (median, } \\
\text { IQR): } 6(5-9)\end{array}$ \\
\hline Rituximaba ${ }^{a}$ & $23(57.5 \%)$ & $\begin{array}{l}\text { Yes: } 17(77.3 \%) \\
\text { Partial: } 3 \\
(13.6 \%) \\
\text { No: } 2(9.1 \%)\end{array}$ & $\begin{array}{l}4+2: 8(36.4 \%) \\
4: 6(27.3 \%) \\
1+1: 6(27.3 \%) \\
\text { Others: } 2(9.1 \%)\end{array}$ \\
\hline Azathioprine & $9(22.5 \%)$ & $\begin{array}{l}\text { Yes: } 1(11.1 \%) \\
\text { Partial: } 4 \\
(44.4 \%) \\
\text { No: } 4(44.4 \%)\end{array}$ & - \\
\hline Mycophenolate & $3(7.5 \%)$ & $\begin{array}{l}\text { Partial: } 1 \\
(33.3 \%) \\
\text { No: } 2(66.7 \%)\end{array}$ & - \\
\hline Methotrexate & $3(7.5 \%)$ & $\begin{array}{l}\text { Partial: } 1 \\
(33.3 \%) \\
\text { No: } 2(66.7 \%)\end{array}$ & - \\
\hline Cyclosporine & $1(2.5 \%)$ & No: 1 (100\%) & - \\
\hline $\begin{array}{l}\text { Interferon beta } \\
1 \mathrm{a}\end{array}$ & $1(2.5 \%)$ & No: 1 (100\%) & - \\
\hline
\end{tabular}

Abbreviations: IVIg = IV immunoglobulin; MP = methylprednisolone; PLEX = plasma exchange.

$4+2: 375 \mathrm{mg} / \mathrm{m}^{2}$ every week for 4 consecutive weeks and then monthly for the next 2 months; $1+1: 21$ g doses separated by 2 weeks; $4: 375 \mathrm{mg} / \mathrm{m}^{2}$ every week for 4 consecutive weeks.

a One patient included in a blinded clinical trial of rituximab vs placebo.

${ }^{b}$ Improvement in mRS after rituximab treatment is detailed in eTable 1 (links.lww.com/NXI/A641).

treatments (mycophenolate, methotrexate, cyclosporine, or interferon betala).

Only 5 of 38 (13.1\%) patients had a good response to IVIg, 10 of $36(27.8 \%)$ patients had a good response to steroids, and 7 of 18 (38.9\%) had a good response to PLEX. On the contrary, 17 of $23(77.3 \%)$ patients had a good response to rituximab and 13 of $23(56.5 \%)$ patients have an improvement of $\geq 2$ points in $\mathrm{mRS}$ after rituximab treatment. Rituximab-treated patients in which mRS remained stable had lower median follow-up time, although differences were not statistically significant (eTable 2, links.lww.com/NXI/A641). Of the 4 rituximab-treated patients without detectable improvement in the mRS score, 2 patients were classified as nonresponders by their primary physicians (median follow-up time of 37 months) and 2 patients were classified as partial responders (median follow-up time of 6 months). Most frequent infusion protocol (36.4\%) was 4 weekly +2 monthly $375 \mathrm{mg} / \mathrm{m}^{2}$ doses, followed by $1+1$ (separated 2 weeks) $1,000 \mathrm{mg}$ doses $(27.3 \%$ ) and 4 weekly 375 $\mathrm{mg} / \mathrm{m}^{2}$ doses $(27.3 \%)$. Five $(21.7 \%)$ patients had a relapse, a median of 21 (4.5-59.5) months after induction with rituximab; 11 (47.8\%) patients received rituximab reinfusions. Four (17\%) patients had adverse effects related to rituximab: 2 mild infusion reactions, 1 pneumonia, and 1 disseminated varicella infection. Treatment frequencies, doses, and responses to treatment are further detailed in Table 2.

The clinical scales at baseline, at nadir, and after treatment are described in Table 1. The median follow-up time was 46 (20-81) months. Patients with facial diplegia had lower maximum and final I-RODS than patients who did not have facial involvement (median maximum I-RODS 22 vs $47, p=$ 0.003 and median final I-RODS 43 vs 61, $p=0.035$ (eTable 3 , links.lww.com/NXI/A641). Three patients died during follow-up: 1 because of CIDP disease course, 1 because of aspiration pneumonia, and 1 because of a disseminated varicella infection. Patients who received rituximab had higher median mRS and lower I-RODS at nadir, although differences were not statistically significant $(4[3-4]$ vs $3[2-4], p=0.5$; 40 [29-49] vs 47 [9-77], $p=0.78$; Table 3). They received a higher number of previous treatments than those patients who did not received rituximab $(4[3-5]$ vs $2[2-3], p=0.03)$, including PLEX, but they did not differ at the final $\mathrm{mRS}$ or I-RODS from those patients not treated with rituximab despite being more drug resistant (Table 3 ). There were no differences between patients treated with PLEX and rituximab $(n=13)$ or with rituximab alone $(n=10)$, regarding response treatment, relapses, or reinfusions needed.

\section{Baseline Immunologic Characteristics}

All sera with an anti-NF155 + CBA were also positive by ELISA; anti-NF155 titers ranged from $1: 300$ to $1: 72,300$. Autoantibodies were predominantly of the IgG4 subclass in all patients. In addition, we evaluated NF155 positivity in 4 CSF from patients with anti-NF155+ AN and 3 of them tested positive for NF155 antibodies. We were able to perform subclass analysis and titration in 2 CSF samples: both were IgG4 and their titers significantly lower than in sera (1:160 in both CSF samples and 1:24,300 and 1:72,300 in sera).

Regarding the HLA genotyping, DRB1*15 alleles (DRB1*15: 01 or $\left.\mathrm{DRB} 1^{*} 15: 02\right)$ were present in 21 of 23 patients with antiNF155+ AN (91.3\%). Most frequent allele was DRB1*15:01 $(\mathrm{n}=13 ; 72.2 \%)$. No clinical differences were observed between patients with $\mathrm{DRB} 1^{*} 15: 01$ and $\mathrm{DRB} 1^{*} 15: 02$, except for a trend to younger age in patients with $\mathrm{DRB1}{ }^{*} 15: 02$ (45.2 \pm 20.5 vs $30.6 \pm 14.6, p=0.14)$. In contrast, HLA-DRB $1^{*} 15$ is found in $17 \%$ of Spanish population, $12 \%$ of North Italy population, $25 \%$ of Southern France population, and 20\% of English population. $^{28}$

\section{Baseline Serum NfL Levels}

Serum NfL levels were determined in all samples available $(36 / 40)$ at baseline. Anti-NF155 + AN patients had 
Table 3 Rituximab Treatment ${ }^{a}$

\begin{tabular}{|c|c|c|c|}
\hline & Patients treated with rituximab $(n=23)$ & Patients not treated with rituximab $(n=16)$ & $p$ Value \\
\hline Age at onset (mean $\pm S D$ ) & $44.1 \pm 20.7$ & $39.25 \pm 18.6$ & 0.51 \\
\hline Age at diagnosis (mean \pm SD) & $45.2 \pm 20.7$ & $39.8 \pm 18.12$ & 0.44 \\
\hline Sex (male; n, \%) & $17(77.3 \%)$ & $11(68.8 \%)$ & 0.41 \\
\hline Baseline NfL levels (median, IQR) $(n=36)$ & $47.69(18.87-154.29)$ & $14.43(7.58-64.68)$ & 0.08 \\
\hline NF155 titers (median, IQR) & $1 / 24,300(1 / 8,100-1 / 24,300)$ & $1 / 8,100(1 / 2,700-1 / 24,300)$ & 0.19 \\
\hline No. of previous treatments (median, IQR) & $4(3-5)$ & $2(2-3)$ & 0.03 \\
\hline $\operatorname{PLEX}(n, \%)$ & $14(63.6 \%)$ & $4(25 \%)$ & 0.02 \\
\hline \multicolumn{4}{|l|}{ mRS (median, IQR) } \\
\hline Baseline $(n=27)$ & $3(2-4)$ & $3(1-4)$ & 0.94 \\
\hline Maximum $(n=37)$ & $4(3-4)$ & $3(2-4)$ & 0.53 \\
\hline Final $(n=37)$ & $2(1-2)$ & $2(1-3)$ & 0.62 \\
\hline \multicolumn{4}{|l|}{ R-ODS (median, IQR) } \\
\hline Baseline $(n=13)$ & $45(40-60)$ & $61(18-86)$ & 0.83 \\
\hline Maximum $(n=16)$ & $40(29-49)$ & $47(9-77)$ & 0.78 \\
\hline Final $(n=21)$ & $58(51-88)$ & $60(55-88)$ & 0.69 \\
\hline
\end{tabular}

significantly higher sNfL levels than $\mathrm{HC}(36.47 \mathrm{pg} / \mathrm{mL}$ vs $7.56 \mathrm{pg} / \mathrm{mL}, p<0.001$, Figure 1 and Table 4$)$ at baseline. sNfL levels correlated with age in $\mathrm{HC}(r=0.73, p<0.001)$ but not in patients with anti-NF155 + AN $(r=0.26$, $p=0.12)$. The samples collected pretreatment $(\mathrm{n}=12)$ have higher sNfL levels than those collected after treatment had been started $(\mathrm{n}=24)(65.84 \mathrm{vs} 18.41 \mathrm{pg} / \mathrm{mL}$; $p=0.002)$.

\section{Relationship Between NF155 Titers, sNfL Levels, and Clinical Status}

Absolute anti-NF155 titers did not correlate with clinical status across patients, but they did when we evaluated follow-up NF155 titers using baseline titers as the reference ( $r=0.41, p=0.004$; eFigures 2 and 3, links.lww.com/NXI/ A641). Baseline sNfL levels negatively correlated with I-RODS at blood sampling $(r=-0.88, p<0.001)$ and with maximum I-RODS achieved $(r=-0.58, p=0.01)$ (eFigure 4, links.lww.com/NXI/A641). However, correlation between the sNfL levels and the final I-RODS $(r=-0.36 ; p=0.1) \mathrm{did}$ not reach statistical significance. sNfL levels correlated with NF155 titers at baseline $(\mathrm{n}=36 ; r=0.43, p=0.001)$ and at every time point available $(\mathrm{n}=105 ; r=0.34, p<0.001)$.

Baseline sNfL levels did not correlate with lowest CMAP in nerve conduction studies in any of the nerves tested. Although patients showing spontaneous activity in the needle EMG of the tibialis anterior showed higher sNfL levels than patients without spontaneous activity ( $67.33 \mathrm{vs} 25.12 \mathrm{pg} / \mathrm{mL}, p=0.1)$, the differences were not statistically significant.

\section{Relationship Between NF155 Titers, sNfL Levels, and Treatment Response to Rituximab: Kinetics}

In rituximab-treated patients with anti-NF155+ AN in which follow-up samples at regular time points were available $(\mathrm{n}=$ 7), antibody titers decreased during follow-up. This decline was significant as early as 3 months after administration of rituximab (mean decrease of $66.7 \%$, Figure 2). At 1 year, a mean titer reduction of $98.6 \%$ in rituximab-treated patients was achieved. In patients not treated with rituximab in which follow-up sample at 1 year $(\mathrm{n}=6)$ was available, no significant decrease of antibodies was observed ( 2 patients had a median decrease of $94 \%, 2$ patients remained stable, and 2 patients increased their NF155 titers) (Figure 3). sNfL levels were higher in rituximab-treated patients compared with those not treated with rituximab $(47.69 \mathrm{vs} 14.43 \mathrm{pg} / \mathrm{mL}, p=$ 0.08 , Table 3 ), but differences were not statistically significant. sNfL levels decreased at 1 year in rituximab-treated patients (median of $37.98 \mathrm{pg} / \mathrm{mL}$ at baseline vs $11.72 \mathrm{pg} / \mathrm{mL}$ at 1 year, $p=0.04)$. In patients not treated with rituximab, median baseline sNfL levels were normal and no changes were observed at 1 year $(7.62 \mathrm{vs} 6.95 \mathrm{pg} / \mathrm{mL}, p=0.16)$. Clinical status improved at 1 year in both groups, but only the rituximab-treated group improved significantly (median of mRS 4 [3-4] at baseline vs $2[1-2]$ at the 1 -year follow-up, 


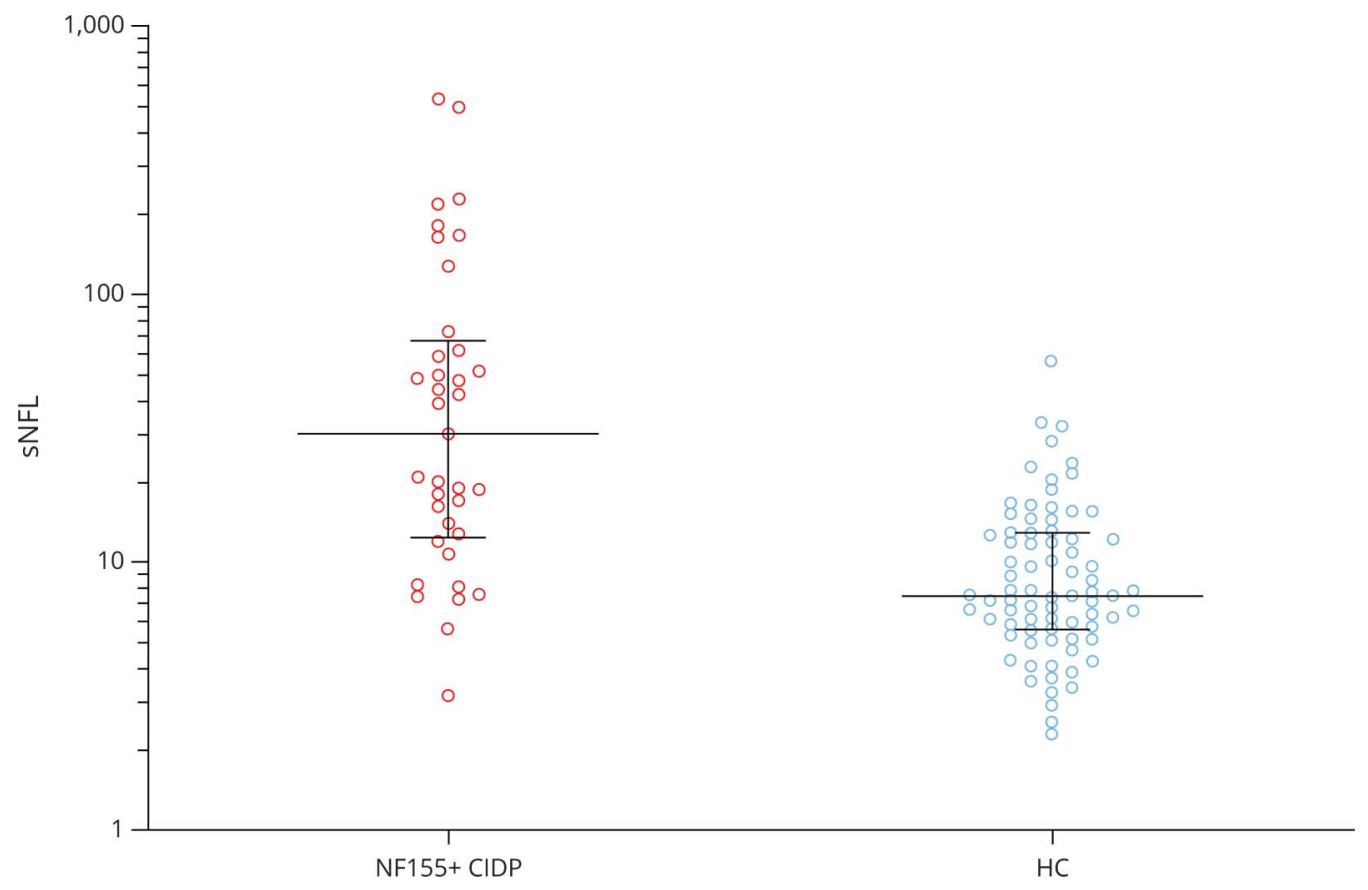

Patients with anti-NF155 + AN had significantly higher sNfL levels than HC. The line in the center represents the median value, and the whiskers indicate the interquartile range. $\mathrm{AN}=$ autoimmune nodopathy; $\mathrm{CIDP}=$ chronic inflammatory demyelinating polyradiculoneuropathy; $\mathrm{HC}=$ healthy control; NF155 = neurofascin-155; sNfL = serum neurofilament light chain.

$p=0.004$, in rituximab-treated AN patients and $3[2-4]$ at baseline vs $2[1-4]$ at 1 year, $p=0.25$, in patients not treated with rituximab).

\section{Discussion}

Our study describes the clinical, laboratory, treatment response and prognostic features of the largest anti-NF155+ AN cohort published so far. ${ }^{3,4,15,29-31}$ It confirms that patients with AN with autoantibodies against NF155 present at a younger age (including a significant proportion of patients below 30 years $)^{5}$ with a specific clinical phenotype with distal weakness, tremor, and ataxia. The presence of these features in a patient fulfilling the CIDP criteria should immediately prompt anti-NF155 antibody testing, as recommended in the recently published revision of the EAN/ PNS CIDP diagnostic guidelines. ${ }^{10}$ Other associated features, which may suggest the presence of anti-NF155 AN and prompt antinodal/paranodal autoantibody testing, are the presence of cranial nerve palsies, particularly facial palsy, high CSF protein content, and poor response to IVIg. An important implication of our study for the testing recommendations in diagnostic guidelines is that almost $10 \%$ of the patients testing positive for anti-NF155 in CBA performed with the myc-DDK tagged NF155 plasmid are false positives. This agrees with our previous observation that demonstrated that a positive test in the NF155 CBA could be due to antibodies targeting the myc-DDK tag and not NF155 itself. $^{32}$ This implies that untagged-NF155 plasmids should be preferentially used and that a second test (ELISA or teased-nerve immunohistochemistry) is always recommended.

Previous case series and systematic reviews suggested that patients with anti-NF155+ AN respond poorly to IVIg or that IVIg response is less frequent than in seronegative CIDP. ${ }^{3,30,31,33}$ This has been described in other IgG4-mediated diseases such as antimuscle-specific tyrosine kinase-positive myasthenia gravis. ${ }^{34}$ There are different hypotheses on why this happens in IgG4mediated diseases, although none has been validated. On the one hand, complement and cell-mediated cytotoxicity do not happen in IgG4 diseases, and thus, any effect that IVIg may have over complement effector mechanisms or cytotoxic cells may be lost. On the other hand, IgG4 is secreted exclusively by IL10+ regulatory B-cells, and these cells, interestingly, have significantly lower expression of the inhibitory immunoglobulin receptor FCGRIIb on their surface (and this could decrease the ability of IgG4-producing cells to be inhibited by IgG). ${ }^{35}$ Our study has also found that most patients with anti-NF155+ AN do not respond appropriately to IVIg (or, to a lower extent, corticosteroids) according to their physicians. On the contrary, most patients respond to rituximab even when they are refractory to IVIg and corticosteroid therapy (this also happens in other IgG4mediated diseases ${ }^{36,37}$ ). More than $50 \%$ of patients in our cohort were treated with rituximab after a poor response to other therapies, and more than $75 \%$ had a good response. This improvement agrees with prospectively collected follow-up $\mathrm{mRS}$ scores that show that most patients improved at least 1 point 
Table 4 Baseline Serum NfL in Anti-NF155 + Patients With AN and Healthy Controls

\begin{tabular}{llll}
\hline & $\begin{array}{l}\text { NF155 + patients } \\
\text { with AN }\end{array}$ & HC & p Value \\
\hline $\begin{array}{l}\text { Age at sampling, } \\
\text { mean } \pm \text { SD }\end{array}$ & $47.87 \pm 20.16$ & $48 \pm 18.1$ & 0.78 \\
\hline Sex, $\mathbf{n}, \%$ male & $28(71.8 \%)$ & $31(39.7 \%)$ & 0.001 \\
\hline sNfL (pg/mL) & & & $<0.001$ \\
\hline $\mathbf{n}$ & 36 & 78 & \\
\hline Median & 36.47 & 7.56 & \\
\hline Max & 536.64 & 56.82 & \\
\hline Min & 3.44 & 2.30 & \\
\hline
\end{tabular}

Abbreviations: $\mathrm{AN}=$ autoimmune nodopathy; $\mathrm{HC}=$ healthy control; NF155 = neurofascin-155; sNfL = serum neurofilament light chain.

(82.6\%), and a significant proportion (56.5\%) improved 2 or more points, despite being resistant to other therapies. Indeed, despite rituximab-treated patients had used a higher number of different drugs and showed higher disability and sNfL levels at baseline, their final prognosis did not differ from patients who responded to first-line therapies. The great benefit that rituximab provides to these patients supports that it could be used as an earlier therapeutic option, although careful assessment of the riskbenefit balance and vaccination status needs to be performed before rituximab treatment, as one patient died due to an infection aggravated by immune-suppresion. Approximately $50 \%$ of the patients in our cohort received PLEX. This is the result of 2 facts: first, patients presented with an aggressive neuropathy that did not respond to first-line therapies and second, because rituximab effect is not clearly seen until the third month of disease and PLEX is used to eliminate as much autoantibody as possible before the use of rituximab to shorten the recovery period. Our study did not find differences in treatment response, relapses, or reinfusions between the group of rituximab-treated patients with anti-NF155 AN pretreated with PLEX and the group nontreated with PLEX, but larger, dedicated studies are needed to clarify the utility of this therapeutic strategy.

Anti-NF155 antibodies are pathogenic according to in vitro and in vivo models. ${ }^{16}$ As such, we hypothesized that their titers should correlate with disease severity. We found that IgG4 antiNF155 antibody titers correlate with clinical status within the same patient, but not across patients. This is something that has been described in other IgG4 autoimmune diseases treated with rituximab, such as anti-muscle-specific tyrosine kinase myasthenia gravis, ${ }^{37,38}$ and in other polyneuropathies as IgM antimyelin-associated glycoprotein neuropathy. ${ }^{39,40}$ Several factors may explain why autoantibody titers do not correlate with clinical activity across patients: autoantibody affinity for their target antigen and diverse biases arising from the retrospective nature of the study (diverse time points, diverse treatment regimens, and diverse baseline severities and ages) among others. However, our study proves that anti-NF155 antibody titers can be a good biomarker for disease activity and treatment response when assessed in individual patients and represented as changes relative to baseline levels. Indeed, in those patients treated with rituximab, IgG4 anti-NF155 decreased more than a $90 \%$ relative to baseline titers or even became negative in a few patients. This suggests that the reappearance or a significant increase in the pathogenic autoantibody may precede a relapse and, thus, could guide treatment reinfusions. Again, this use of the autoantibodies needs to be validated prospectively, but the temporal evolution of the autoantibody titers, paralleling the sNfL levels and the clinical status in the few patients in which prospective follow-up was available, is promising.

We identified IgG4 anti-NF155 antibodies in the CSF of 3 of 4 patients in which a CSF sample was available. Intrathecal antipan neurofascin has been previously described, ${ }^{41}$ and anti-NF155 antibodies in CSF have been described in 2 patients with combined central and peripheral demyelination ${ }^{42}$ but not in anti-NF155 AN so far. The high protein content in CSF, the absence of oligoclonal bands, and the presence of higher anti-NF155 titers in serum than in CSF suggests that anti-NF155 antibodies appear in the CSF because of blood-brain barrier disruption and not because of intrathecal synthesis. The presence of these autoantibodies in the CSF could help explaining the cerebellar features in patients with anti-NF155+ AN, but larger cohorts including patients with and without tremor in which CSF is analyzed are needed.

Our study also showed that sNfL levels were higher in patients with anti-NF155+ AN than in HC. High sNfL levels have also been recently described in CIDP, particularly in a small subset of patients with anti-NF155+ AN who showed higher sNfL levels than seronegative CIDP. ${ }^{18}$ In our study, we found a

Figure 2 Clinical Status, NF155 Titers, and sNfL Levels After Rituximab Treatment Induction: Kinetics

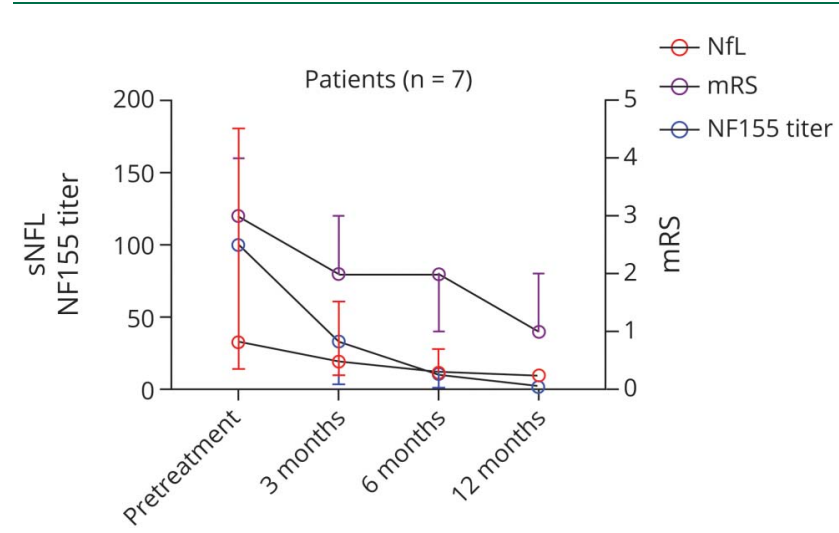

Rituximab treated anti-NF-155 patients with follow-up samples at regular time points show improvement in the mRS scale, a decrease in NF155 titers, and a decrease in sNfL levels starting on the third month of treatment infusion. The line in the center represents the median value, and the whiskers indicate the interquartile range. $\mathrm{mRS}=$ modified Rankin Scale; NF155 = neurofascin-155; NF155 = neurofascin-155; sNfL = serum neurofilament light chain. 
A. Patients treated with Rituximab $(n=10)$

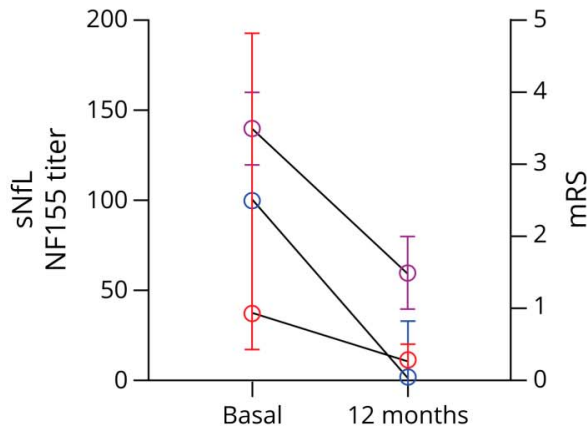

B. Patients treated with IVlg and/or corticosteroids $(n=6)$

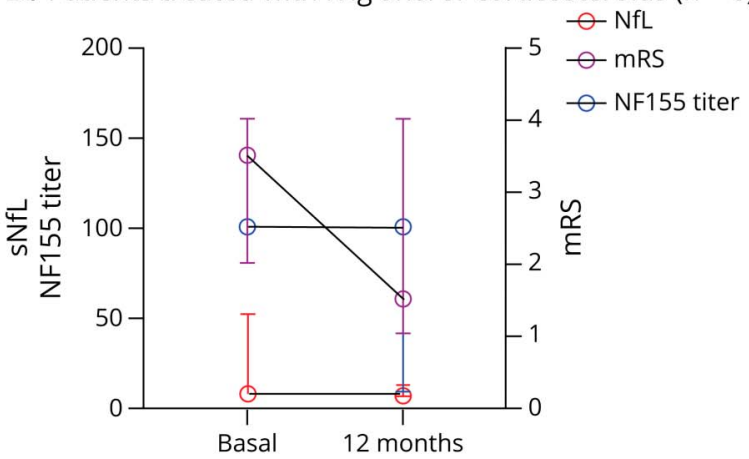

Clinical improvement is present in patients treated with first-line therapies or rituximab but only the rituximab-treated group improved significantly. AntiNF155 titers and sNfL levels decreased only in rituximab-treated group. The line in the center represents the median value, and the whiskers indicate the interquartile range. IVIg = IV immunoglobulin; mRS= modified Rankin Scale; NF155= neurofascin-155; sNfL= serum neurofilament light chain.

strong correlation between baseline sNfL levels and initial I-RODS and maximum I-RODS achieved, but not with final I-RODS, suggesting that the final outcomes are not completely determined by initial severity because effective therapies change the course of the disease and most patients improve significantly, regardless of the treatment used. These data differ from those found in GBS, ${ }^{24}$ a monophasic disorder in which initial events determine long-term outcomes, but nonetheless suggest that sNfL may be useful to monitor disease because it seems to happen in other peripheral neuropathies. ${ }^{43-45}$

Our study was not designed to correlate sNfL levels with electrophysiologic parameters because EMG and sNfL levels were not performed at the same time points, but we explored potential correlations between CMAP amplitudes, the presence of spontaneous activity at distal, most affected, muscles, and sNfL levels. We failed to find strong associations. sNfL levels did not correlate with CMAP amplitudes, but they tended to be higher in patients with spontaneous activity. Thus, our results, although preliminary, support the ability of sNfL to monitor axonal damage. Altogether, the correlation of $\mathrm{sNfL}$ with disability scales and, less strongly, with the appearance of residual disability or spontaneous activity agrees with the relatively frequent presence of distal muscle atrophy because of secondary axonal damage that some of these patients display and would support the use of sNfL as an early marker of potential axonal damage that could guide treatment selection to prevent the appearance of this permanent damage.

sNfL levels and anti-NF155 antibody titers decreased in all patients in which prospective follow-up was performed on rituximab therapy, whereas neither sNfL or anti-N155 levels showed comparable changes with other treatments. The observation of the rituximab-treated prospectively followed subset of patients suggests, considering the caveats of clinical evaluation in monitoring disease activity in autoimmune neuropathies, that monitoring sNfL levels that inform about the tissue status and anti-NF155 titers that inform about the immunologic effector mechanism, at regular intervals after treatment, could be useful to guide treatment choices and detect suboptimal therapeutic responses. Hypothetically, an eventual increase in autoantibody titers or sNfL levels could herald a subsequent relapse and detecting the biomarker increase could help prevent it. However, the need of retreatment should be assessed individually based on patient's clinical status and not only based on the laboratory data.

HLA loci are the group of genetic factors that has most frequently been associated with autoimmune diseases, including strong associations with other IgG4-mediated diseases. ${ }^{46-48}$ Previous studies have shown a strong association between a specific Class II allele, HLA-DRB1*15 (either 15:01 or 15: 02 ), and patients with anti-NF155+ AN. ${ }^{13}$ Our study shows a stronger association than previously reported (91.3\%), confirming that this HLA allele is a constitutive risk factor that, associated with unknown environmental factors, may be driving the appearance of the anti-NF155 autoantibodies. The study of this genetic association in conjunction with geographic distribution of the disorder, lifestyle, concomitant disorders, microbiome, or environmental triggers may yield interesting pathophysiologic insights but requires significantly larger cohorts of patients.

The main limitations of our study arise from the small number of patients and its retrospective nature, including the retrospective analysis of treatment efficacy using chart review. Furthermore, considering that patients were identified through routine diagnostic testing, it is likely that our cohort is enriched in patients with tremor or a lack of response to IVIg because of selection bias. However, since anti-NF155+ AN account for, approximately, $5 \%$ of all patients with CIDP, with 40 patients, our cohort provides the largest cohort in which a comprehensive clinical, serologic, and treatment response analysis has been performed. 
In conclusion, our study confirms that anti-NF155+ AN constitutes a defined subset of patients with characteristic clinical, epidemiologic, and immunologic features that response to IVIg and steroids is often poor, whereas rituximab is an effective therapy for most patients and that anti-NF155 antibody titers and sNfL levels could be used in combination to monitor clinical activity, ongoing axonal damage, and treatment response.

\section{Acknowledgment}

The authors would like to acknowledge the Department of Medicine at the Universitat Autònoma de Barcelona. Several authors of this publication are members of the European Reference Network for rare neuromuscular diseases (EURONMD).

\section{Study Funding}

This work is supported by Fondo de Investigaciones Sanitarias (FIS), Instituto de Salud Carlos III, Spain and FEDER under grant FIS19/0140 and personal grant INT20/00080, personal grant GBS-CIDP Foundation to CL, personal grant Rio Hortega CM19/00042 to LMA and the ER20P3AC7624 project of the ACCI call of the CIBERER network, Madrid, Spain. XSC was supported by a "Sara Borrell" postdoctoral fellowship project "CD18/ 00195," funded by Instituto de Salud Carlos III and cofunded by European Union (ERDF/ESF, "A way to make Europe"/ "Investing in your future"). A.C. thanks the Medical Research Council (MR/T001712/1), the Fondazione CARIPLO (2019-1836), the Italian Ministry of Health-Ricerca Corrente, the Inherited Neuropathy Consortium (INC) and Fondazione Regionale per la Ricerca Biomedica for grant suport.

\section{Disclosure}

L. Querol has provided expert testimony for Grifols, SanofiGenzyme, Novartis, UCB, Roche and CSL Behring and received research funds from Novartis Spain, Sanofi-Genzyme and Grifols. L. Martín-Aguilar has received speaking honoraria from Roche. E. Pascual-Goñi has received speaking honoraria from Roche and Biogen. J. Díaz-Manera has provided expert testimony for PTC and Sanofi-Genzyme, has been external advisor for Sanofi, Sarepta and Audentes and received research funds from Sanofi-Genzyme and Boehringer. G. Liberatore reported travel grants to attend scientific meetings from CSL Behring and Kedrion. M. Cabrera-Serrano has received honoraria from Biogen for scientific translation works. K. Pitarokoili received travel grants and speakers' honoraria from Novartis, Biogen idec, Teva, Bayer, Celgene, CSL Behring and Grifols, all not related to the manuscript. The other authors report no disclosures. Go to Neurology.org/NN for full disclosures.

\section{Publication History}

Received by Neurology: Neuroimmunology \& Neuroinflammation March 2, 2021. Accepted in final form September 27, 2021.

\section{Appendix Authors}

\begin{tabular}{lll}
\hline Name & Location & Contribution \\
\hline $\begin{array}{l}\text { Lorena } \\
\text { Martín- } \\
\text { Aguilar, MD, } \\
\text { PhD }\end{array}$ & $\begin{array}{l}\text { Hospital de la Santa Creu i } \\
\text { Sant Pau, IIB-Sant Pau } \\
\text { Barcelona, Spain }\end{array}$ & $\begin{array}{l}\text { Acquisition of data, } \\
\text { performed the experiments, } \\
\text { analyzed the data, drafted } \\
\text { the manuscript for } \\
\text { intellectual content }\end{array}$ \\
\hline $\begin{array}{l}\text { Cinta Lleixà, } \\
\text { MSc }\end{array}$ & $\begin{array}{l}\text { Hospital de la Santa Creu i } \\
\text { Sant Pau, IlB-Sant Pau } \\
\text { Barcelona, Spain }\end{array}$ & $\begin{array}{l}\text { Acquisition of data, } \\
\text { performed the experiments, } \\
\text { drafted and revised the } \\
\text { manuscript for intellectual } \\
\text { content }\end{array}$ \\
& & $\begin{array}{l}\text { Acquision of data, revised } \\
\end{array}$
\end{tabular}

\begin{tabular}{lll}
\hline $\begin{array}{l}\text { Elba Pascual- } \\
\text { Goñi, MD, } \\
\text { PhD }\end{array}$ & $\begin{array}{l}\text { Hospital de la Santa Creu i } \\
\text { Sant Pau, IlB-Sant Pau } \\
\text { Barcelona, Spain }\end{array}$ & $\begin{array}{l}\text { Acquisition of data, revised } \\
\text { the manuscript for } \\
\text { intellectual content }\end{array}$ \\
\hline $\begin{array}{l}\text { Marta } \\
\text { Caballero, } \\
\text { MD }\end{array}$ & $\begin{array}{l}\text { Hospital de la Santa Creu i } \\
\text { Sant Pau, Barcelona, Spain }\end{array}$ & $\begin{array}{l}\text { Acquisition of data, revised } \\
\text { the manuscript for } \\
\text { intellectual content }\end{array}$ \\
\hline $\begin{array}{l}\text { Laura } \\
\text { Martínez- } \\
\begin{array}{l}\text { Martínez, } \\
\text { MD, PhD }\end{array}\end{array}$ & $\begin{array}{ll}\text { Sospital de la Santa Creu i } \\
\text { Sau, Barcelona, Spain }\end{array}$ & $\begin{array}{l}\text { Performed HLA } \\
\text { experiments and analyzed } \\
\text { the data, revised the } \\
\text { manuscript for intellectual } \\
\text { content }\end{array}$ \\
\hline
\end{tabular}

Jordi Diaz- Hospital de la Santa Creu i Acquisition of samples and Manera, MD, Sant Pau, Barcelona, Spain data. Revised the PhD manuscript for intellectual content

\begin{tabular}{lll}
\hline Ricard Rojas- & Hospital de la Santa Creu i & $\begin{array}{l}\text { Acquisition of samples and } \\
\text { data, revised the } \\
\text { García, MD, }\end{array}$ \\
PhD & Sant Pau, Barcelona, Spain & $\begin{array}{l}\text { manuscript for intellectual } \\
\text { content }\end{array}$
\end{tabular}

Elena Cortés- Hospital de la Santa Creu i Acquisition of samples and Vicente, MD, Sant Pau, IIB-Sant Pau data, revised the

PhD Barcelona, Spain manuscript for intellectual content

Janina Turón- Hospital de la Santa Creu i Acquisition of samples and Sans, MD Sant Pau, Barcelona, Spain data, revised the manuscript for intellectual content

\begin{tabular}{|c|c|c|}
\hline $\begin{array}{l}\text { Noemí de } \\
\text { Luna, PhD }\end{array}$ & $\begin{array}{l}\text { IIB-Sant Pau Barcelona, } \\
\text { Spain }\end{array}$ & $\begin{array}{l}\text { Revised the manuscript for } \\
\text { intellectual content }\end{array}$ \\
\hline $\begin{array}{l}\text { Xavier } \\
\text { Suárez- } \\
\text { Calvet, PhD }\end{array}$ & $\begin{array}{l}\text { IIB-Sant Pau Barcelona, } \\
\text { Spain }\end{array}$ & $\begin{array}{l}\text { Revised the manuscript for } \\
\text { intellectual content }\end{array}$ \\
\hline $\begin{array}{l}\text { Eduard } \\
\text { Gallardo, PhD }\end{array}$ & $\begin{array}{l}\text { IIB-Sant Pau Barcelona, } \\
\text { Spain }\end{array}$ & $\begin{array}{l}\text { Revised the manuscript for } \\
\text { intellectual content }\end{array}$ \\
\hline $\begin{array}{l}\text { Yusuf } \\
\text { Rajabally, MD }\end{array}$ & $\begin{array}{l}\text { University Hospital } \\
\text { Birmingham, Birmingham, } \\
\text { UK }\end{array}$ & $\begin{array}{l}\text { Acquisition of samples and } \\
\text { data, revised the } \\
\text { manuscript for intellectual } \\
\text { content }\end{array}$ \\
\hline $\begin{array}{l}\text { Sangeeta } \\
\text { Scotton, MD }\end{array}$ & $\begin{array}{l}\text { University Hospital } \\
\text { Birmingham, Birmingham, } \\
\text { UK }\end{array}$ & $\begin{array}{l}\text { Acquisition of samples and } \\
\text { data, revised the } \\
\text { manuscript for intellectual } \\
\text { content }\end{array}$ \\
\hline $\begin{array}{l}\text { Bart C. } \\
\text { Jacobs, MD, } \\
\text { PhD }\end{array}$ & $\begin{array}{l}\text { Erasmus Medical Center, } \\
\text { Rotterdam, The } \\
\text { Netherlands }\end{array}$ & $\begin{array}{l}\text { Acquisition of samples and } \\
\text { data, revised the } \\
\text { manuscript for intellectual } \\
\text { content }\end{array}$ \\
\hline $\begin{array}{l}\text { Adája Baars, } \\
\text { MD }\end{array}$ & $\begin{array}{l}\text { Erasmus Medical Center, } \\
\text { Rotterdam, The } \\
\text { Netherlands }\end{array}$ & $\begin{array}{l}\text { Acquisition of samples and } \\
\text { data, revised the } \\
\text { manuscript for intellectual } \\
\text { content }\end{array}$ \\
\hline
\end{tabular}


Appendix (continued)

\begin{tabular}{lll}
\hline Name & Location & Contribution \\
\hline $\begin{array}{l}\text { Andrea } \\
\begin{array}{l}\text { Cortese, MD, } \\
\text { PhD }\end{array}\end{array}$ & IRCCS Mondino Foundation, & $\begin{array}{l}\text { Acquisition of samples and } \\
\text { data, revised the } \\
\text { manuscript for intellectual } \\
\text { content }\end{array}$ \\
\hline $\begin{array}{l}\text { Elisa Vegezzi, } \\
\text { MD }\end{array}$ & $\begin{array}{l}\text { IRCCS Mondino Foundation, } \\
\text { Pavia, Italy }\end{array}$ & $\begin{array}{l}\text { Acquisition of samples and } \\
\text { data, revised the } \\
\text { manuscript for intellectual } \\
\text { content }\end{array}$
\end{tabular}

\begin{tabular}{ll}
\hline Romana & Medical University of \\
Höftberger, & Vienna, Vienna, Austria \\
MD &
\end{tabular}

Acquisition of samples and data, revised the manuscript for intellectual content

Fritz Medical University of

Zimprich, MD Vienna, Vienna, Austria

Acquisition of samples and data, revised the manuscript for intellectual content

\begin{tabular}{lll}
\hline $\begin{array}{l}\text { Cornelia } \\
\text { Roesler, MD }\end{array}$ & $\begin{array}{l}\text { Paracelsus Medical } \\
\text { University, Salzburg, Austria }\end{array}$ & $\begin{array}{l}\text { Acquisition of samples and } \\
\text { data, revised the } \\
\text { manuscript for intellectual } \\
\text { content }\end{array}$ \\
\hline $\begin{array}{l}\text { Eduardo } \\
\text { Nobile- } \\
\text { Orazio, MD, } \\
\text { PhD }\end{array}$ & $\begin{array}{l}\text { Humanitas Clinical and } \\
\text { Research Institute, Milan, } \\
\text { Italy }\end{array}$ & $\begin{array}{l}\text { Acquisition of samples and } \\
\text { data, revised the } \\
\text { manuscript for intellectual } \\
\text { content }\end{array}$ \\
\hline $\begin{array}{l}\text { Giuseppe } \\
\text { Liberatore, } \\
\text { MD }\end{array}$ & $\begin{array}{l}\text { Humanitas Clinical and } \\
\text { Research Institute, Milan, } \\
\text { Italy }\end{array}$ & $\begin{array}{l}\text { Acquisition of samples and } \\
\text { data, revised the } \\
\text { manuscript for intellectual } \\
\text { content }\end{array}$ \\
\hline
\end{tabular}

\begin{tabular}{lll}
\hline Hiew Fu & Kuala Lumpur General \\
Liong, MD & $\begin{array}{l}\text { Hospital, Jalan Pahang, } \\
\text { Kuala Lumpur, Malaysia }\end{array}$ & $\begin{array}{l}\text { Acquisition of samples and } \\
\text { data, revised the } \\
\text { manuscript for intellectual } \\
\text { content }\end{array}$ \\
& &
\end{tabular}

\begin{tabular}{|c|c|c|}
\hline $\begin{array}{l}\text { Alicia } \\
\text { Martínez- } \\
\text { Piñeiro, MD }\end{array}$ & $\begin{array}{l}\text { Hospital Universitari } \\
\text { Germans Trias i Pujol, } \\
\text { Badalona, Spain }\end{array}$ & $\begin{array}{l}\text { Acquisition of samples and } \\
\text { data, revised the } \\
\text { manuscript for intellectual } \\
\text { content }\end{array}$ \\
\hline
\end{tabular}

Alejandra Hospital Universitario de

Acquisition of samples and data, revised the manuscript for intellectual content
Raquel Piñar- Hospital Universitario Acquisition of samples and Morales, MD Clínico San Cecilio, Granada, data, revised the Spain manuscript for intellectual content

\begin{tabular}{lll}
\hline Mercedes & Hospital Son Llàtzer, Palma & Acquisition of samples and \\
Usón-Martín, & de Mallorca, Spain & $\begin{array}{l}\text { data, revised the } \\
\text { mD }\end{array}$ \\
& & $\begin{array}{l}\text { content } \\
\text { conteript for intellectual }\end{array}$
\end{tabular}

Olalla Albertí, Hospital San Jorge, Huesca, Acquisition of samples and MD Spain data, revised the manuscript for intellectual content

\begin{tabular}{lll}
\hline $\begin{array}{l}\text { Maria } \\
\begin{array}{l}\text { Ángeles } \\
\text { López-Pérez, } \\
\text { MD }\end{array}\end{array}$ & $\begin{array}{l}\text { Hospital San Pedro, } \\
\text { Logroño, Spain }\end{array}$ & $\begin{array}{l}\text { Acquisition of samples and } \\
\text { data, revised the } \\
\text { manuscript for intellectual } \\
\text { content }\end{array}$ \\
\hline $\begin{array}{l}\text { Fabián } \\
\text { Márquez, MD }\end{array}$ & $\begin{array}{ll}\text { Hospital Universitari Josep } \\
\text { Trueta, Girona, Spain }\end{array}$ & $\begin{array}{l}\text { Acquisition of samples and } \\
\text { data, revised the } \\
\text { manuscript for intellectual } \\
\text { content }\end{array}$ \\
\hline
\end{tabular}

Appendix (continued)

\begin{tabular}{|c|c|c|}
\hline Name & Location & Contribution \\
\hline $\begin{array}{l}\text { Julio Pardo- } \\
\text { Fernandez, } \\
\text { MD, PhD }\end{array}$ & $\begin{array}{l}\text { Hospital Clínico } \\
\text { Universitario de Santiago, } \\
\text { Santiago de Compostela, } \\
\text { Spain }\end{array}$ & $\begin{array}{l}\text { Acquisition of samples and } \\
\text { data, revised the } \\
\text { manuscript for intellectual } \\
\text { content }\end{array}$ \\
\hline $\begin{array}{l}\text { Laura Muñoz- } \\
\text { Delgado, MD }\end{array}$ & $\begin{array}{l}\text { Hospital Universitario } \\
\text { Virgen del Rocío, Sevilla, } \\
\text { Spain }\end{array}$ & $\begin{array}{l}\text { Acquisition of samples and } \\
\text { data, revised the } \\
\text { manuscript for intellectual } \\
\text { content }\end{array}$ \\
\hline $\begin{array}{l}\text { Macarena } \\
\text { Cabrera- } \\
\text { Serrano, MD, } \\
\text { PhD }\end{array}$ & $\begin{array}{l}\text { Hospital Universitario } \\
\text { Virgen del Rocío, Sevilla, } \\
\text { Spain }\end{array}$ & $\begin{array}{l}\text { Acquisition of samples and } \\
\text { data, revised the } \\
\text { manuscript for intellectual } \\
\text { content }\end{array}$ \\
\hline $\begin{array}{l}\text { Nicolau Ortiz, } \\
\text { MD, PhD }\end{array}$ & $\begin{array}{l}\text { Hospital Universitari Sant } \\
\text { Joan de Reus, Tarragona, } \\
\text { Barcelona }\end{array}$ & $\begin{array}{l}\text { Acquisition of samples and } \\
\text { data, revised the } \\
\text { manuscript for intellectual } \\
\text { content }\end{array}$ \\
\hline $\begin{array}{l}\text { Manuel } \\
\text { Bartolomé, } \\
\text { MD }\end{array}$ & $\begin{array}{l}\text { Complejo Asistencial de } \\
\text { Ávila, Ávila, Spain }\end{array}$ & $\begin{array}{l}\text { Acquisition of samples and } \\
\text { data, revised the } \\
\text { manuscript for intellectual } \\
\text { content }\end{array}$ \\
\hline $\begin{array}{l}\text { Özgür } \\
\text { Duman, MD }\end{array}$ & $\begin{array}{l}\text { Akdeniz University, Antalya, } \\
\text { Turkey }\end{array}$ & $\begin{array}{l}\text { Acquisition of samples and } \\
\text { data, revised the } \\
\text { manuscript for intellectual } \\
\text { content }\end{array}$ \\
\hline Vera Bril, MD & $\begin{array}{l}\text { Toronto General Hospital, } \\
\text { University Health Network, } \\
\text { University of Toronto, } \\
\text { Toronto, Canada }\end{array}$ & $\begin{array}{l}\text { Acquisition of samples and } \\
\text { data, revised the } \\
\text { manuscript for intellectual } \\
\text { content }\end{array}$ \\
\hline $\begin{array}{l}\text { Darwin } \\
\text { Segura- } \\
\text { Chávez, MD }\end{array}$ & $\begin{array}{l}\text { Instituto Nacional de } \\
\text { Ciencias Neurológicas, } \\
\text { Lima, Perú }\end{array}$ & $\begin{array}{l}\text { Acquisition of samples and } \\
\text { data, revised the } \\
\text { manuscript for intellectual } \\
\text { content }\end{array}$ \\
\hline $\begin{array}{l}\text { Kalliopi } \\
\text { Pitarokoili, } \\
\text { MD }\end{array}$ & $\begin{array}{l}\text { St. Josef-Hospital, Ruhr- } \\
\text { University Bochum, } \\
\text { Bochum, Germany }\end{array}$ & $\begin{array}{l}\text { Acquisition of samples and } \\
\text { data, revised the } \\
\text { manuscript for intellectual } \\
\text { content }\end{array}$ \\
\hline $\begin{array}{l}\text { Claudia } \\
\text { Steen, MD }\end{array}$ & $\begin{array}{l}\text { Sant Joseph Hospital, Berlin, } \\
\text { Germany }\end{array}$ & $\begin{array}{l}\text { Acquisition of samples and } \\
\text { data, revised the } \\
\text { manuscript for intellectual } \\
\text { content }\end{array}$ \\
\hline $\begin{array}{l}\text { Isabel Illa, } \\
\text { MD, PhD }\end{array}$ & $\begin{array}{l}\text { Hospital de la Santa Creu } \\
\text { i Sant Pau, Barcelona, } \\
\text { Spain }\end{array}$ & $\begin{array}{l}\text { Revised the manuscript for } \\
\text { intellectual content }\end{array}$ \\
\hline $\begin{array}{l}\text { Luis Querol, } \\
\text { MD, PhD }\end{array}$ & $\begin{array}{l}\text { Hospital de la Santa Creu i } \\
\text { Sant Pau, Barcelona, Spain }\end{array}$ & $\begin{array}{l}\text { Design and conceptualized } \\
\text { the study, interpreted the } \\
\text { data; revised the } \\
\text { manuscript for intellectual } \\
\text { content }\end{array}$ \\
\hline
\end{tabular}

\section{References}

1. Lehmann HC, Burke D, Kuwabara S. Chronic inflammatory demyelinating polyneuropathy: update on diagnosis, immunopathogenesis and treatment. J Neurol Neurosurg Psychiatry. 2019;90(9):981-987.

2. Mathey EK, Park SB, Hughes RA, et al. Chronic inflammatory demyelinating polyradiculoneuropathy: from pathology to phenotype. J Neurol Neurosurg Psychiatry. 2015;86(9):973-985.

3. Querol L, Nogales-Gadea G, Rojas-Garcia R, et al. Neurofascin IgG4 antibodies in CIDP associate with disabling tremor and poor response to IVIg. Neurology. 2014: 82(10):879-886.

4. Delmont E, Manso C, Querol L, et al. Autoantibodies to nodal isoforms of neurofascin in chronic inflammatory demyelinating polyneuropathy. Brain. 2017;140(7):1851-1858. 
5. Querol L, Nogales-Gadea G, Rojas-Garcia R, et al. Antibodies to contactin-1 in chronic inflammatory demyelinating polyneuropathy. Ann Neurol. 2013;73(3): 370-380.

6. Doppler K, Appeltshauser L, Villmann C, et al. Auto-antibodies to contactinassociated protein 1 (Caspr) in two patients with painful inflammatory neuropathy. Brain. 2016;139(pt 10):2617-2630.

7. Pascual-Goñi E, Fehmi J, Lleixà $\mathrm{C}$, et al. Antibodies to the Caspr1/contactin-1 complex in chronic inflammatory demyelinating polyradiculoneuropathy. Brain. 2021:144(4):1183-1196.

8. Pascual-Goñi E, Martín-Aguilar L, Querol L. Autoantibodies in chronic inflammatory demyelinating polyradiculoneuropathy. Curr Opin Neurol. 2019;32(5):651-657.

9. Querol L, Devaux J, Rojas-Garcia R, Illa I. Autoantibodies in chronic inflammatory neuropathies: diagnostic and therapeutic implications. Nat Rev Neurol. 2017:13(9):533-547.

10. Van den Bergh PYK, Doorn PA, Hadden RDM, et al. European Academy of Neurology/Peripheral Nerve Society Guideline on diagnosis and treatment of chronic inflammatory demyelinating polyradiculoneuropathy: report of a Joint Task Force Second Revision. J Peripher Nerv Syst. 2021:26(3):242-268.

11. Painous C, López-Pérez MÁ, Illa I, Querol L. Head and voice tremor improving with immunotherapy in an anti-NF155 positive CIDP patient. Ann Clin Transl Neurol. 2018;5(4):499-501.

12. Kouton L, Boucraut J, Devaux J, et al. Electrophysiological features of chronic inflammatory demyelinating polyradiculoneuropathy associated with IgG4 antibodies targeting neurofascin 155 or contactin 1 glycoproteins. Clin Neurophysiol. 2020; 131(4):921-927.

13. Martinez-Martinez L, Lleixà MC, Boera-Carnicero G, et al. Anti-NF155 chronic inflammatory demyelinating polyradiculoneuropathy strongly associates to HLADRB15. J Neuroinflammation. 2017;14(1):1-6.

14. Querol L, Rojas-García R, Diaz-Manera J, et al. Rituximab in treatment-resistant CIDP with antibodies against paranodal proteins. Neurol Neuroimmunol Neuroinflamm. 2015;2(5):e149.

15. Cortese A, Lombardi R, Briani C, et al. Antibodies to neurofascin, contactin-1, and contactin-associated protein 1 in CIDP: clinical relevance of IgG isotype. Neurol Neuroimmunol Neuroinflamm. 2020;7(1):e639.

16. Manso C, Querol L, Lleixà C, et al. Anti-neurofascin-155 IgG4 antibodies prevent paranodal complex formation in vivo. J Clin Invest. 2019;129(6):2222-2236.

17. Koike H, Kadoya M, Kaida KI, et al. Paranodal dissection in chronic inflammatory demyelinating polyneuropathy with anti-neurofascin-155 and anti-contactin-1 antibodies. J Neurol Neurosurg Psychiatry. 2017;88(6):465-473.

18. Fukami Y, Iijima M, Koike H, Yamada S, Hashizume A, Katsuno M. Association of serum neurofilament light chain levels with clinicopathology of chronic inflammatory demyelinating polyneuropathy, including NF155 reactive patients. J Neurol. 2021: 268(10):3835-3844.

19. Van den Bergh PYK, Hadden RDM, Bouche P, et al. European Federation of Neurological Societies/Peripheral Nerve Society Guideline on management of chronic inflammatory demyelinating polyradiculoneuropathy: Report of a Joint Task Force of the European Federation of Neurological Societies and the Peripher. Eur J Neurol. 2010;17:356-363.

20. Breiner A, Bourque PR, Allen JA. Updated cerebrospinal fluid total protein reference values improve chronic inflammatory demyelinating polyneuropathy diagnosis. Muscle Nerve. 2019;60(9):180-183.

21. Quinn TJ, Dawson J, Walters MR, Lees KR. Functional outcome measures in contemporary stroke trials. Int J Stroke. 2009;4(9):200-205.

22. Van Nes SI, Vanhoutte EK, Van Doorn PA, et al. Rasch-built Overall Disability Scale (RODS) for immune-mediated peripheral neuropathies. Neurology. 2011;76(9):337-345.

23. Querol L, Siles AM, Alba-Rovira R, et al. Antibodies against peripheral nerve antigens in chronic inflammatory demyelinating polyradiculoneuropathy. Sci Rep. 2017;7(9):14411.

24. Martín-Aguilar L, Camps-Renom $P$, Lleixà $C$, et al. Serum neurofilament light chain predicts long-term prognosis in Guillain-Barré syndrome patients. J Neurol Neurosurg Psychiatry. 2021;92:70-77.
25. Athanasopoulos D, Motte J, Fisse AL, et al. Longitudinal study on nerve ultrasound and corneal confocal microscopy in NF155 paranodopathy. Ann Clin Transl Neurol. 2020;7(6):1061-1068.

26. De Simoni D, Ricken G, Winklehner M, et al. Antibodies to nodal/paranodal proteins in paediatric immune-mediated neuropathy. Neurol Neuroimmunol Neuroinflammation. 2020;7(4):e763.

27. Verghese A, Hiew FL, Chia YK, Querol L. Visual pathway demyelination in neurofascin-155 IGG4- positive combined central and peripheral demyelination. J Neurol Sci. 2019;405:196-197.

28. Allele Frequency Net Database. Accessed October 29, 2021. allelefrequencies.net

29. Ogata H, Yamasaki R, Hiwatashi A, et al. Characterization of IgG4 anti-neurofascin 155 antibody-positive polyneuropathy. Ann Clin Transl Neurol. 2015;2(10):960-971.

30. Devaux JJ, Miura Y, Fukami Y, et al. Neurofascin-155 IgG4 in chronic inflammatory demyelinating polyneuropathy. Neurology. 2016;86(9):800-807.

31. $\mathrm{Hu} \mathrm{W}, \mathrm{Xin} \mathrm{Y}, \mathrm{He} \mathrm{Z}$, Zhao Y. Association of neurofascin IgG4 and atypical chronic inflammatory demyelinating polyneuropathy: a systematic review and meta-analysis. Brain Behav. 2018;8(10):e01115.

32. Martín-Aguilar L, Pascual-Goñi E, Lleixà C, et al. Antibodies against nodo-paranodal proteins are not present in genetic neuropathies. Neurology. 2020;95(4):e427-e433.

33. Guo X, Tang L, Huang $\mathrm{Q}$, Tang X. A systematic review and meta-analysis of autoantibodies for diagnosis and prognosis in patients with chronic inflammatory demyelinating Polyradiculoneuropathy. Front Neurosci. 2021:15:637336.

34. Oh SJ, Morgan MB, Lu L, et al. Different characteristic phenotypes according to antibody in myasthenia gravis. J Clin Neuromuscul Dis. 2012;14(2):57-65.

35. Van De Veen W, Stanic B, Yaman G, et al. IgG4 production is confined to human IL10-producing regulatory $\mathrm{B}$ cells that suppress antigen-specific immune responses. J Allergy Clin Immunol. 2013;131(4):1204-1212.

36. Joly P, Mouquet H, Roujeau J-C, et al. A single cycle of rituximab for the treatment of severe pemphigus. N Engl J Med. 2007;357(6):545-552.

37. Díaz-Manera J, Martínez-Hernández E, Querol L, et al. Long-lasting treatment effect of rituximab in MuSK myasthenia. Neurology. 2012;78(3):189-193.

38. Marino M, Basile U, Spagni G, et al. Long-Lasting rituximab-induced reduction of specific-but not total-IgG4 in MuSK-positive myasthenia gravis. Front Immunol. 2020;11:1-9.

39. Svahn J, Petiot P, Antoine JC, et al. Anti-MAG antibodies in 202 patients: clinicopathological and therapeutic features. J Neurol Neurosurg Psychiatry. 2018;89(5): 499-505.

40. Dalakas MC, Rakocevic G, Salajegheh M, et al. Placebo-controlled trial of rituximab in IgM anti-myelin-associated glycoprotein antibody demyelinating neuropathy. Ann Neurol. 2009;65(3):286-293.

41. Stengel H, Vural A, Brunder AM, et al. Anti-pan-neurofascin IgG3 as a marker of fulminant autoimmune neuropathy. Neurol Neuroimmunol Neuroinflamm. 2019;6(5): e603.

42. Kawamura N, Yamasaki R, Yonekawa T, et al. Anti-neurofascin antibody in patients with combined central and peripheral demyelination. Neurology. 2013;81(8):714-722.

43. Lieverloo GGA, Wieske L, Verhamme C, et al. Serum neurofilament light chain in chronic inflammatory demyelinating polyneuropathy. J Peripher Nerv Syst. 2019; 24(2):187-194.

44. Sandelius $\AA$, Zetterberg H, Blennow K, et al. Plasma neurofilament light chain concentration in the inherited peripheral neuropathies. Neurology. 2018;90(6):e518-e524.

45. Kapoor M, Foiani M, Heslegrave A, et al. Plasma neurofilament light chain concentration is increased and correlates with the severity of neuropathy in hereditary transthyretin amyloidosis. J Peripher Nerv Syst. 2019:24(4):314-319.

46. Niks EH, Kuks JBM, Roep BO, et al. Strong association of MuSK antibody-positive myasthenia gravis and HLA-DR14-DQ5. Neurology. 2006;66(11):1772-1774.

47. Huijbers MG, Querol LA, Niks EH, et al. The expanding field of IgG4-mediated neurological autoimmune disorders. Eur J Neurol. 2015;22(8):1151-1161.

48. Kim TJ, Lee ST, Moon J, et al. Anti-LGIl encephalitis is associated with unique HLA subtypes. Ann Neurol. 2017;81(2):183-192. 


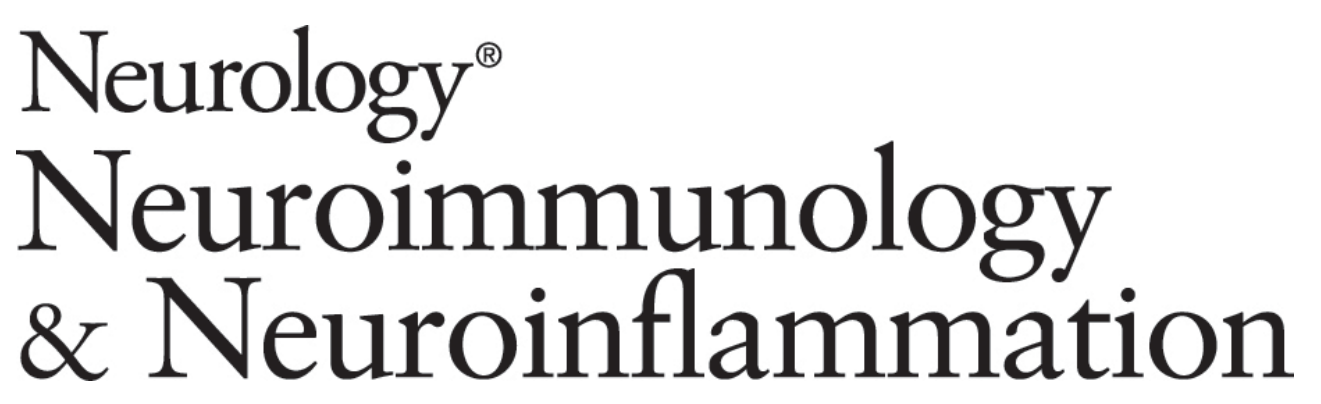

\author{
Clinical and Laboratory Features in Anti-NF155 Autoimmune Nodopathy \\ Lorena Martín-Aguilar, Cinta Lleixà, Elba Pascual-Goñi, et al. \\ Neurol Neuroimmunol Neuroinflamm 2022;9; \\ DOI 10.1212/NXI.0000000000001098
}

This information is current as of November 2, 2021

Neurol Neuroimmunol Neuroinflamm is an official journal of the American Academy of Neurology.

Published since April 2014, it is an open-access, online-only, continuous publication journal. Copyright

Copyright $\odot 2021$ The Author(s). Published by Wolters Kluwer Health, Inc. on behalf of the American Academy of Neurology.. All rights reserved. Online ISSN: 2332-7812.

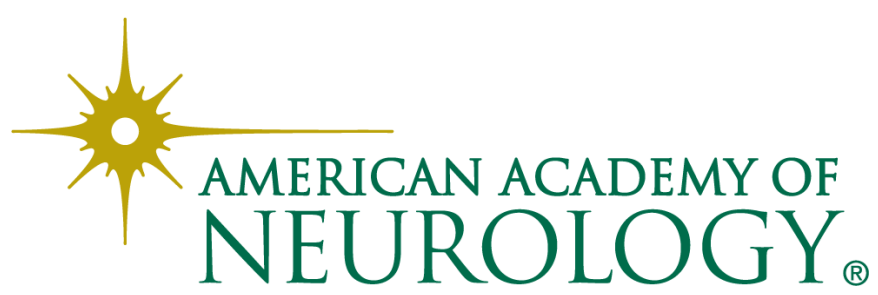




\section{Updated Information \& Services}

References

Citations

Subspecialty Collections

\section{Errata}

Permissions \& Licensing

Reprints including high resolution figures, can be found at: http://nn.neurology.org/content/9/1/e1098.full.html

This article cites 47 articles, 7 of which you can access for free at: http://nn.neurology.org/content/9/1/e1098.full.html\#\#ref-list-1

This article has been cited by 1 HighWire-hosted articles: http://nn.neurology.org/content/9/1/e1098.full.html\#\#otherarticles

This article, along with others on similar topics, appears in the following collection(s):

Chronic inflammatory demyelinating polyneuropathy

http://nn.neurology.org//cgi/collection/chronic_inflammatory_demyeli nating_polyneuropathy

\section{Class IV}

http://nn.neurology.org//cgi/collection/class_iv

An erratum has been published regarding this article. Please see next page or:

/content/9/1/e1129.full.pdf

Information about reproducing this article in parts (figures,tables) or in its entirety can be found online at:

http://nn.neurology.org/misc/about.xhtml\#permissions

Information about ordering reprints can be found online:

http://nn.neurology.org/misc/addir.xhtml\#reprintsus

Neurol Neuroimmunol Neuroinflamm is an official journal of the American Academy of Neurology.

Published since April 2014, it is an open-access, online-only, continuous publication journal. Copyright

Copyright $\odot 2021$ The Author(s). Published by Wolters Kluwer Health, Inc. on behalf of the American Academy of Neurology.. All rights reserved. Online ISSN: 2332-7812.

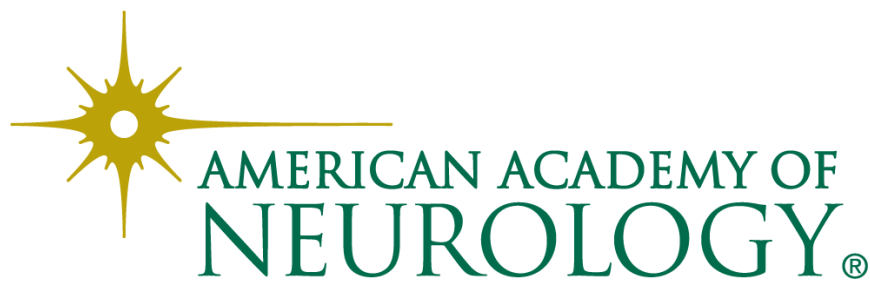




\section{CORRECTION}

\section{Clinical and Laboratory Features in Anti-NF155 Autoimmune Nodopathy}

Neurol Neuroimmunol Neuroinflamm 2022;9:e1129. doi:10.1212/NXI.0000000000001129

In the Article "Clinical and Laboratory Features in Anti-NF155 Autoimmune Nodopathy" by Martín-Aguilar et al., ${ }^{1}$ the affiliation for author Eduardo Nobile-Orazio should have been listed as "IRCCS Humanitas Research Hospital, Milan University, Rozzano, Italy." The publisher regrets the error.

\section{Reference}

1. Martín-Aguilar L, Lleixà C, Pascual-Goñi E, et al. Clinical and laboratory features in anti-nf155 autoimmune nodopathy. Neurol Neuroimmunol Neuroinflamm. 2022;9(1):e1098. doi: 10.1212/NXI.0000000000001098. 